\title{
Spatial variability of the hydraulic properties of a drip irrigated andisol under blueberries
}

\author{
Dec, $\mathrm{D}^{1,2^{*}}$, Dörner, J., \\ ${ }^{1}$ Instituto de Ingeniería Agraria y Suelos, Facultad de Ciencias Agrarias, Universidad Austral de Chile, Valdivia, Chile. ${ }^{2}$ Centro \\ de Investigación en Suelos Volcánicos, Universidad Austral de Chile, Valdivia, Chile. ${ }^{*}$ Corresponding author:dorota.dec@uach.cl
}

\begin{abstract}
The objective of the present investigation was to identify the spatial variability of hydraulic properties of a volcanic ash soil under irrigated Blueberry crops, in order to improve the irrigation efficiency in a very sensitive crop by excess or lack of water. Undisturbed samples $\left(230 \mathrm{~cm}^{3}\right.$ ) were collected in area of $945 \mathrm{~m}^{2}$ (grid: 72 points separated by 3.2 and $6.4 \mathrm{~m}$ ) between 1 and $7 \mathrm{~cm}$ depth in an Acrudoxic Fulvudands to determine the bulk density (Bd), total porosity (TP), the volume of water-filled pore space $\left(\mathrm{ea}_{(6 \mathrm{kPa})}\right)$, plant available water $(\mathrm{PAW})$, permanent wilting point (PWP) and saturated hydraulic conductivity (Ks). Along with sampling, volumetric water content $\left(\theta_{\text {(Field })}\right)$ was measured using a TDR (grid: 120 points spaced by 1.4 and $3.2 \mathrm{~m}$ ). From all results contour maps were developed, using geostatistical tools. The coefficient of variation of $\left(\theta_{(\mathrm{Field})}\right), \mathrm{Ks},\left(\mathrm{ea}_{(6 \mathrm{kPa})}\right)$ and PAW showed a moderate variability $(15 \%-35 \%)$. The dependence degree (DD) was considered as weak for $\theta_{(\text {Field })}$, moderate for $\theta_{(6 \mathrm{kPa})}, \mathrm{ea}_{(6 \mathrm{kPa})}, \mathrm{PAW}$ and high for Bd, TP, Ks and $\theta_{(0.1 \mathrm{kPa})}$. The properties with largest DD were soil structure-dependent, whereas, the lowest values were observed for those related to soil texture (in this case $\theta_{\text {(Field) }}$, which were close to the PMP). The spatial variability was related to the high water storage capacity and the ability of the soil to conduct water with different intensities, what is related to the amount of water-filled macropores.
\end{abstract}

Keywords: Variability of soil physical properties, efficient irrigation, water storage capacity, volcanic soils

\section{Introduction}

The Blueberry (Vaccinium corymbosum) was introduced in Chile during the 80's. The planting surface in 1995 increased three times on a global level and increases every year. The surface area under Blueberries for year 2012 was 13.162 ha with about 3.000 ha in the $X$ and XIV Regions (González Zagal, 2013). Most of these plantations are under volcanic soils, and have a high input of technology, particularly, pressured irrigation systems. The increasing surface of Blueberries under irrigation drives that the pressure on water resources becomes stronger every year. This means that the precision farming, which aims to crop-oriented cultivation methods with site-specific actions, becomes increasingly important.

Proper water application in the Blueberry crop is a determinant factor in their growth and production, since the majority of roots, which reach $0.5 \mathrm{~m}$ depth (Bryla, 2011), are concentrated in the surface. Other characteristics are a small amount of root hair, which is 
the principal way to absorb water, however this restricted volume of roots hairs conditions their ability to absorb water (Holzapfel et al., 2004; Bryla, 2011) and make them very susceptible to water stress with variations in soil water contents, so that the water availability is very important on every stage of this crop's development. The sufficient rain or irrigation becomes critical from time fruit set and the canopy develops until after-harvest during fruit bud set (Bryla, 2011). Water inefficiency in one of these stages can produce reduction of fruit weight, diameter and number of flower buds (Mingeau et al., 2001), with the consequent reduction of yield on the current and following years as well as the wood production (Bryla, 2011). Holzapfel et al. (2004) mentioned that growth and production especially in Highbush Blueberry, are associated with constant and reasonable soil water content during the season, which means that the amount of applied water must consider the water demand of the crop, the plant features as size, density, root development and the water-air relationship determined by soil specific characteristics.

The most common types of irrigation for Blueberry crops are microjet and drip irrigation. In southern Chile, the majority of Blueberry crops are irrigated by drip systems, which are used for soils with a high water holding capacity (Holzapfel et al., 2004). The characteristic of this system is their high efficiency of irrigation $(>80 \%)$ and fertilization (Zeng et al., 2013), so that the amounts of water applied to the soil are smaller and the area wetted by the dripper is restricted, but the irrigation frequency is in fact higher as compared to the other systems.

These characteristics are fulfilled when the system is: i) properly designed, ii) well-managed and appropriate to climatic conditions and iii) when the variation of soil properties are also considered (Timm et al., 2010).

In general it is assumed that the soil physical and hydraulic properties are constant in space and time. Regarding the hydraulic properties, this means that the soil water holding capacity does not change over the years and is the same for the whole cultivated area.
This situation is not valid for many soils (e.g. Schwen et al., 2011) including Andisols in southern Chile as described by Dörner et al. (2012) and Dec et al. (2011 and 2012). Spatial variations of soil hydraulic properties were also described by Guimaraes et al. (2010), who mentioned that to increase the water use efficiency in agriculture, it is necessary to consider the spatial variation of soil properties as: bulk density, porosity and soil water holding capacity. In these terms, the spatial variability of the physical properties of Andisols has not been thoroughly reported, in fact, only recently the soil water content and mechanical impedance were described (Dec et al., 2011). At the same time, Dörner et al. (2012) and Dec et al. (2012) assessed that these particular soils show a dynamic behaviour depending on soil management and wetting and drying cycles, which induce spatial variations in soil physical properties (Schwen et al., 2011). These spatial variations should be investigated to improve the water distribution and reduce plant water stress, which is relevant considering the susceptibility of Blueberry to the lack and excess of water (Bryla and Strik, 2007; Mingeau et al., 2001). Additionally, irrigation systems, which consider the variability of soil hydraulic properties, allow the avoidance of root development reduction and their susceptibility to disease in case of prolonged high soil moisture contents, as well as, the reduction of soil erosion and nutrient leaching.

The consideration of the spatial variability of soil hydraulic properties in the design of drip irrigation systems for Blueberry crops with superficial root systems is relevant to improve the water use efficiency and to reduce the well-known susceptibility of blueberries to water stress. One of the tools used in the last years is the preparation of soil maps using geostatistic and spatial interpolation of pointbased measurements of soil properties (e.g. Timm et al., 2010). Therefore, in order to study the spatial variability structure of physical properties relevant for irrigation, the aim of this investigation was to analyse the spatial variability of soil hydraulic properties of a volcanic ash soil under drip-irrigated Blueberry. 


\section{Material and Methods}

\subsection{Soil and management}

The experimental field was located in Mafil, 45 $\mathrm{km}$ from Valdivia, Chile $\left(39^{\circ} 48^{\prime} \mathrm{S}, 73^{\circ} 15^{\prime} \mathrm{E}, 12 \mathrm{~m}\right.$ a.s.1.) in a farm called "Rucapichio". The studied soil (Serie Llastuco) was a moderately deep Andosol, Acrudoxic Hapludand with a silty loam texture in the first centimetres, which became finer, and below 100 $\mathrm{cm}$ coarser with more or less cemented and mixed tuff locally called "cancagua" (CIREN, 2003). These soils, which have a nearly flat topography with a slope between 1 and $3 \%$, were developed from volcanic ashes deposited on a cancagua. The average annual temperature in the area is $12{ }^{\circ} \mathrm{C}$, precipitations can reach $2500 \mathrm{~mm}$ per year with a strong concentration in the winter and the annual evapotranspiration is close to $963 \mathrm{~mm}$ (CIREN, 1997).

In the study site there is a plantation of Highbush Blueberry (Vaccinium corymbosum L.), variety Brigitta (5 years old). In order to establish the plantation, the soil was tilled and "mounded rows" (ridges $20 \mathrm{~cm}$ high and $80 \mathrm{~cm}$ wide) were built up to increase the soil depth. The Blueberries were planted every $1.33 \mathrm{~m}$ in the mounded rows (distanced at $2 \mathrm{~m}$ ), which were previously covered with plastic to improve the weed control. The orchard has a drip irrigation system with two dripper lines situated at the soil surface (distance between drippers: $0.33 \mathrm{~m}$; Q of dripper $=2.1 \mathrm{~L} / \mathrm{h}$ ) for each plant. The last irrigation was 5 days before soil sampling, so that the soil was dried and soil cracks were visible in the first soil centimetres.

\subsection{Field measurements and soil sampling}

The experiment was conducted in area of $945 \mathrm{~m}^{2}$ (3 plots of $21 \mathrm{mx} 15 \mathrm{~m}$ ). Before sampling, a gouge auger (Eijkelkamp) was used to determine the homogeneity of the soil as a function of its effective depth and morphological variation. As described by CIREN (2003) the soil presents a silty loam texture in the whole experimental field. The soil sampling was conducted in January 2012, at least 5 days after the last irrigation. Every investigated plot included 5 rows, which were divided as grid with distance of $3.2 \times 2.8 \mathrm{~m}$. In these points (120 in total) at depth between 1 and $7 \mathrm{~cm}$, the volumetric water content $\left(\theta_{\text {(Field })}\right)$ was measured with TDR (W.E.T.-2-K1 Sensor, DELTA-T DEVICES LTD., England). Before start the measurements the device was calibrated in accordance to the standard sets by producer. After these measurements, between 1 and $7 \mathrm{~cm}$ depth, 72 undisturbed soil cores in steel cylinders $\left(230 \mathrm{~cm}^{3}\right)$ in a grid of $3.2 \times 5.6 \mathrm{~m}$ were collected. These samples were used to determine the soil hydraulic properties under laboratory conditions.

\subsection{Laboratory analysis}

The disturbed soil samples were air-dried and then sieved to a $2 \mathrm{~mm}$ size. The soil texture was determined using the hydrometer method after the organic matter was destroyed using $\mathrm{H}_{2} \mathrm{O}_{2}$ (Day, 1965). Cementing agents were eliminated with $\mathrm{Na}_{2} \mathrm{~S}_{2} 0_{4}, \mathrm{Na}_{3} 0_{7} \mathrm{C}_{6} \mathrm{H}_{5}(0.3$ $\mathrm{M})$ and $\mathrm{CH}_{3} \mathrm{COONa}(1 \mathrm{M})$ and clay was dispersed with $\mathrm{Na}_{4} \mathrm{P}_{2} \mathrm{O}_{7}(0.1 \mathrm{~N})$. The particle density was measured with the pycnometer method (Klute, 1986). Organic carbon was determined using Walkley and Black's method (1934).

In order to study the hydraulic properties of the soil, the soil bulk density, the volumetric water content $(\theta)$ at different water tensions $(0.1,6$ and $(1543 \mathrm{kPa})$ and saturated hydraulic conductivity (Ks) were measured. The undisturbed soil samples were saturated by capillary rise from beneath for 48 hours. When saturated, the samples were first weighed to define $\theta_{0.1 \mathrm{kPa}}$ and then equilibrated at a water tension of $6 \mathrm{kPa}$, using sand tanks, to register $\theta_{(6 \mathrm{kPa})}$ (considered as field capacity). Thereafter, the samples were located inside the water permeameter (Eijkelkamp, model 09.02.01.25) and saturated again for 24 hours. The Ks measurements were conducted 1 hour after beginning the constant water flow through the soil samples (Dörner et al., 2010). The volumetric water content at a water tension of $1543 \mathrm{kPa}$ $\left(\theta_{1543 \mathrm{kPa}}\right)$ was measured in $20 \mathrm{~cm}^{3}$ soil samples using a pressure chamber (Hartge and Horn, 2009). 
From the $\theta$ measured at different water tensions, the water-filled pore space at $6 \mathrm{kPa}\left(\mathrm{ea}_{(6 \mathrm{kPa})}\right)$ as well as the plant available water (PAW) was calculated. The water-filled pore space [\% Vol.] was defined as:

$$
e_{(6 k P a)}=\theta_{(0.1 k P a)}-\theta_{(6 k P a)}
$$

This soil physical parameter was used, since it reflected the amount of pores, which contribute effectively to the water flow under near-saturated conditions. The amount of this volume of pores is lower than the air capacity (TP - ${ }_{\theta 6 \mathrm{kPa}}$, with TP: total porosity) because the soil pores normally do not get fully saturated (van Genuchten, 1980).

The plant available water [\% Vol.] was calculated as:

$$
P A W=\theta_{(6 k P a)}-\theta_{(1543 k P a)}
$$

\subsection{Statistical analyses}

For the descriptive statistics, mean, max and min values as well as coefficient of variation, skewness and kurtosis were calculated. The Ks-values were log-transformed because of the skewed distribution (Hartge and Horn, 2009). Outliers were not considered and defined using Box-Plots analyses. The spatial variability structure was analyzed using the geostatistical software GS + version 9.0. This program allows the definition of semivariograms and their respective parameters set (nugget $\mathrm{Co}$; sill $\mathrm{Co}+\mathrm{C}$, range $\mathrm{A})$. The best mathematical model was chosen based on the highest coefficient of determination $\left(\mathrm{R}^{2}\right)$ and the lowest residual sum of squares (RSS). The dependence degree (DD) was calculated using the ratio $\mathrm{Co} /(\mathrm{Co}+\mathrm{C})$ considered as strong when $\mathrm{DD}<25 \%$, moderate when $25 \%<$ $\mathrm{DD}<75 \%$ and weak when DD $>75 \%$, as proposed by Cambardella et al. (1994). More details about geostatistical analyses can be found in Robertson (2008). Finally, in order to understand the spatial variability of Ks, linear regressions were conducted.

\section{Results}

\subsection{Descriptive statistics and geostatistical parameters of the Andisol's hydraulic properties}

The descriptive statistics of the hydraulic properties of the studied volcanic ash soil are presented in Table 1. According to the values of skewness and kurtosis almost all studied properties presented normal distribution, which was confirmed by the Kolmogorov-Smirnov Test. Values of bulk density (Bd) ranged between 0.43 and $0.73 \mathrm{~g} \mathrm{~cm}^{-3}$, total porosity (TP) reached $82 \%$ and the volumetric field water content $\left(\theta_{\text {(Field) }}\right)$ varied between 13 and $30 \%$. The volumetric water content at field capacity $\left(\theta_{(6 \mathrm{kPa})}\right)$ presented the largest differences in the field, ranging from 32 until $59 \%$. The same was also true for waterfilled pore space $\left(\mathrm{ea}_{\left({ }_{(6 \mathrm{kPa} a}\right)}\right)$, plant available water $(\mathrm{PAW})$ and saturated hydraulic conductivity (Ks), properties highly variables, with $\mathrm{CV}>15 \%$.

The variation coefficients of the soil properties are high for all investigated properties, (considering that the samples are form the same management unit), with the highest values of 44.7 for $\mathrm{ea}_{(6 \mathrm{kPa})}$ and the lowest with value of 3.6 for TP (Table 1). To understand the spatial structure of the hydraulic properties, the parameters derived from semivariograms are presented in Table 2. All studied properties presented a defined structure of spatial variability and the models, which better described this behaviour were: exponential for $\theta_{(0.1 \mathrm{kPa})}, \theta_{(6 \mathrm{kPa})}$, PAW and Ks; linear for $\theta_{\text {(Field })}$ and $\mathrm{ea}_{(6 \mathrm{kPa})}$ and Gaussian for $\mathrm{Bd}$ and TP. The dependence degree (DD) was considered as a weak for only $\theta_{\text {(Field) }}$ with value of $100 \%$. Properties as $\theta_{(6 \mathrm{kPa})}, \mathrm{ea}_{(6 \mathrm{kPa})}$ and PAW showed moderate DD with values of 26,52 and $32.6 \%$, respectively, and a range (A: the separation distance over which spatial dependence is apparent) of $300 \mathrm{~m}$ for $\theta_{(6 \mathrm{kPa})}$ and $350 \mathrm{~m}$ for PAW. Bulk density, total porosity and $\theta_{(0.1 \mathrm{kPa})}$ presented high dependence degree with values of 17,22 and $9 \%$, respectively. The range was as follows: 141,120 and $16 \mathrm{~m}$ for the same soil properties. Strong DD with value of 0.1 was observed only in case of Ks, with a range of $18.6 \mathrm{~m}$. 
Table 1. Descriptive statistics of the Andisol's hydraulic properties.

\begin{tabular}{lllllllll}
\hline SHP & $\begin{array}{l}\theta_{\text {(Field })} \\
{[\% \text { Vol. }]}\end{array}$ & $\begin{array}{l}\mathrm{Bd} \\
{\left[\mathrm{g} / \mathrm{cm}^{3}\right]}\end{array}$ & $\begin{array}{l}\text { TP } \\
{[\% \mathrm{Vol} .]}\end{array}$ & $\begin{array}{l}\theta_{(0.1 \mathrm{kPa})} \\
{[\% \mathrm{Vol} .]}\end{array}$ & $\begin{array}{l}\theta_{(6 \mathrm{kPa})} \\
{[\% \text { Vol. }]}\end{array}$ & $\begin{array}{l}\mathrm{ea}_{(6 \mathrm{kPa})} \\
{[\% \text { Vol. }]}\end{array}$ & $\begin{array}{l}\text { PAW } \\
{[\% \text { Vol. }]}\end{array}$ & $\begin{array}{l}\text { Ks } \\
{[\mathrm{log} \mathrm{cm} / \mathrm{d}]}\end{array}$ \\
\hline $\mathrm{n}$ & 120 & 69 & 69 & 69 & 69 & 63 & 69 & 60 \\
Mean & 19.9 & 0.56 & 75.8 & 55.8 & 45.1 & 9.5 & 32.7 & 2.0 \\
Median & 20.1 & 0.56 & 76.4 & 55.8 & 46.4 & 8.3 & 34.1 & \\
CV & 16.6 & 11.8 & 3.6 & 11.6 & 16.3 & 44.7 & 25.65 & 23.08 \\
Min. & 13.0 & 0.43 & 69.4 & 38.3 & 31.8 & 4.7 & 18.8 & 1.07 \\
Max. & 29.9 & 0.73 & 82.1 & 68.8 & 59.1 & 21.4 & 46.1 & 3.06 \\
Skewness & 0.204 & 0.211 & -0.211 & -0.149 & -0.078 & 0.954 & -0.010 & 0.264 \\
Curtosis & 0.294 & 0.179 & 0.180 & -0.126 & -0.990 & 0.192 & -0.952 & -0.277 \\
K-S Test & 0.2 & 0.2 & 0.2 & 0.2 & 0.2 & $0.137(\mathrm{~ns})$ & 0.2 & $0.018(\mathrm{~ns})$ \\
\hline
\end{tabular}

$\theta_{\text {(Field })}:$ Volumetric water content in the field, TP: Total porosity, Bd: Bulk density, $\theta_{(0.1 \mathrm{kPa})}$ and $\theta_{(6 \mathrm{kPa})}$ : Volumetric water content at 0.1 and $6 \mathrm{kPa}$ water tension, $\mathrm{ea}_{(6 \mathrm{kPa})}$ : water-filled pore space at $6 \mathrm{kPa}, \mathrm{PAW}$ : Plan Available Water, Ks: Saturated Hydraulic Conductivity, (ns): not significant.

Table 2. Geostatistical parameters of the Andisol's hydraulic properties.

\begin{tabular}{|c|c|c|c|c|c|c|c|c|}
\hline SHP & $\begin{array}{l}\theta_{\text {(Field) }} \\
{[\% \text { Vol.] }}\end{array}$ & $\begin{array}{l}\mathrm{Bd} \\
{\left[\mathrm{g} / \mathrm{cm}^{3}\right]}\end{array}$ & $\begin{array}{l}\text { TP } \\
{[\% \text { Vol. }]}\end{array}$ & $\begin{array}{l}\theta_{(0.1 \mathrm{kPa})} \\
{[\% \mathrm{Vol} .]}\end{array}$ & $\begin{array}{l}\theta_{(6 \mathrm{kPa})} \\
{[\% \mathrm{Vol} .]}\end{array}$ & $\begin{array}{l}\mathrm{ea}_{(6 \mathrm{kPa})} \\
{[\% \mathrm{Vol} .]}\end{array}$ & $\begin{array}{l}\text { PAW } \\
{[\% \text { Vol.] }}\end{array}$ & $\begin{array}{l}\mathrm{Ks} \\
{[\log \mathrm{cm} / \mathrm{d}]}\end{array}$ \\
\hline Model & Linear & Gaussian & Gaussian & Exponential & Exponential & Linear & Exponential & Exponential \\
\hline Co & 10.06 & 0.00275 & 4.94 & 4 & 22.1 & 9.40 & 29.1 & 0.0001 \\
\hline $\mathrm{Co}+\mathrm{C}$ & 10.06 & 0.0164 & 22.73 & 42.57 & 85.2 & 18.12 & 89.2 & 0.19 \\
\hline Ao & 22.3 & 81.3 & 69.1 & 5.34 & 99.9 & 22.43 & 116.55 & 6.21 \\
\hline $\mathrm{R}^{2}$ & 0.53 & 0.89 & 0.89 & 0.229 & 0.64 & 0.45 & 0.47 & 0.13 \\
\hline RSS & 0.784 & $6.8 * 10^{-7}$ & 2.2 & 81.3 & 286 & 36.2 & 431 & $7.2 * 10^{-3}$ \\
\hline DD & 100 & 17 & 22 & 9 & 26 & 52 & 32.6 & 0.1 \\
\hline A & - & 141 & 120 & 16 & 300 & - & 350 & 18.6 \\
\hline
\end{tabular}

$\theta_{\text {(Field) }}$ : Volumetric water content in the field, TP: Total porosity, Bd: Bulk density, $\theta_{(0.1 \mathrm{kPa})}$ and $\theta_{(6 \mathrm{kPa})}$ : Volumetric water content at 0.1 and $6 \mathrm{kPa}$ water tension, $\mathrm{ea}_{(6 \mathrm{kPa})}$ : water-filled pore space at $6 \mathrm{kPa}$, PAW: Plan Available Water, Ks: Saturated Hydraulic Conductivity.

\subsection{Spatial variability of the Andisol's hydraulic properties}

The bulk density (Bd) and total porosity (TP) measured on the undisturbed soil samples under laboratory conditions and $\theta_{\text {(Field) }}$ determined by TDR were used to prepare maps of their spatial distribution (Figure 1). As the porosity of the soil depends on their bulk density, they were spatial related: areas with high Bd (Figure 1a) corresponded to those with low TP (Figure 1b). Also $\theta_{\text {(Field) }}$ presented spatial variation (Figure 1c), however, this was less pronounced than other properties presenting values near to the permanent wilting point (18\% to this soil, data not pressented) The soil water content determined under laboratory conditions was used to prepare the contour maps presented in Figure 2. For saturated conditions, the soil water content presented two defined areas with values ranging from near 70 vol. $\%$ to 50 vol. $\%$. A spatial variation was also observed for the volumetric water content at field capacity, however, no clear relationships between $\theta_{(0.1 \mathrm{kPa})}$ and $\theta_{(6 \mathrm{kPa})}$ were observed. Nevertheless, the areas with higher punctual values of water content at saturated conditions were situated in part of the experimental field with higher field capacity values (first $28 \mathrm{~m}$ ). 


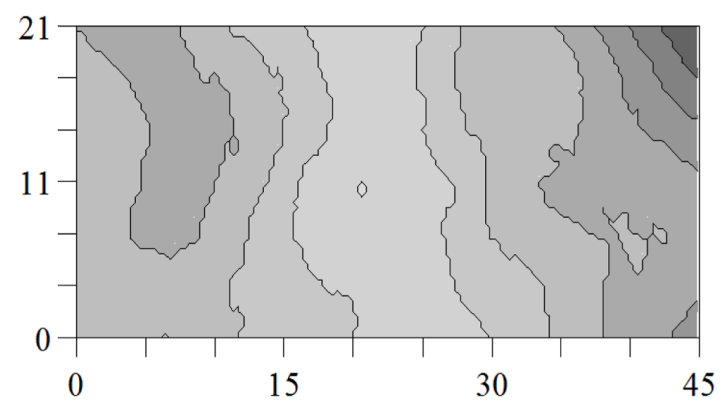

a)

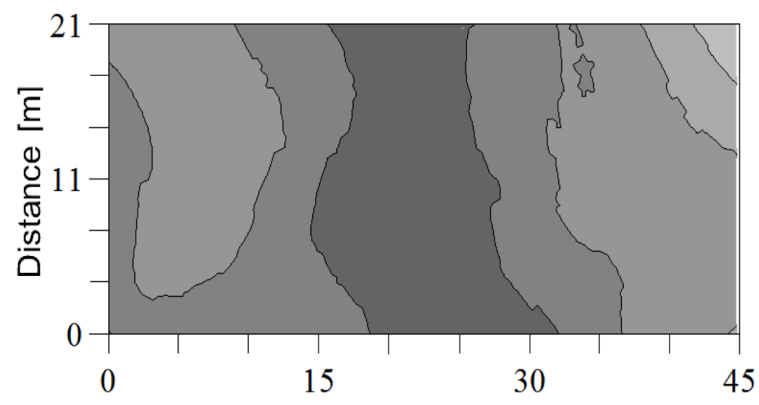

b)

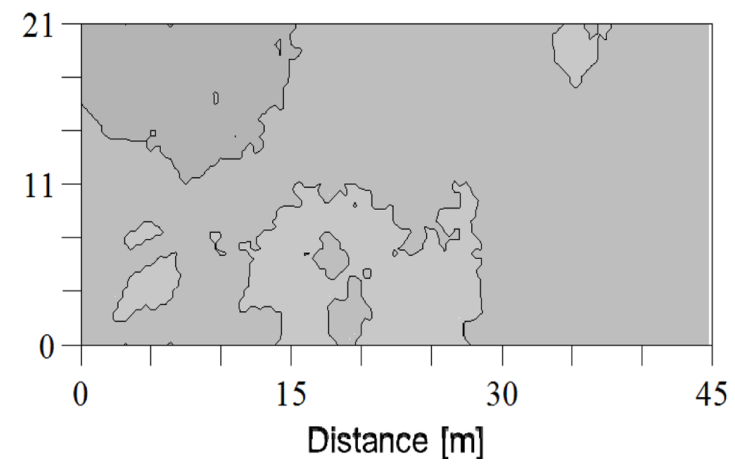

c)

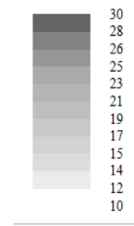

Figure 1. Spatial variability of: (a) soil bulk density $\left[\mathrm{g} \mathrm{cm}^{-3}\right]$, (b) total porosity [Vol. \%] and (c) field water content [Vol. \%].

The hydraulic properties relevant for the irrigation of the Blueberries are presented in Figure 3. As presented in Table 2, the water-filled pore space and saturated hydraulic conductivity parameters presented a defined structure of spatial variability. In these terms, regions of the maps with higher amount of water-filled macropores agree with lower areas of plant available water (PAW) and higher areas of saturated hydraulic conductivity. The latter is clearly seen in Figure 4, which shows linear increase of Ks as a function of water-filled macropores. 

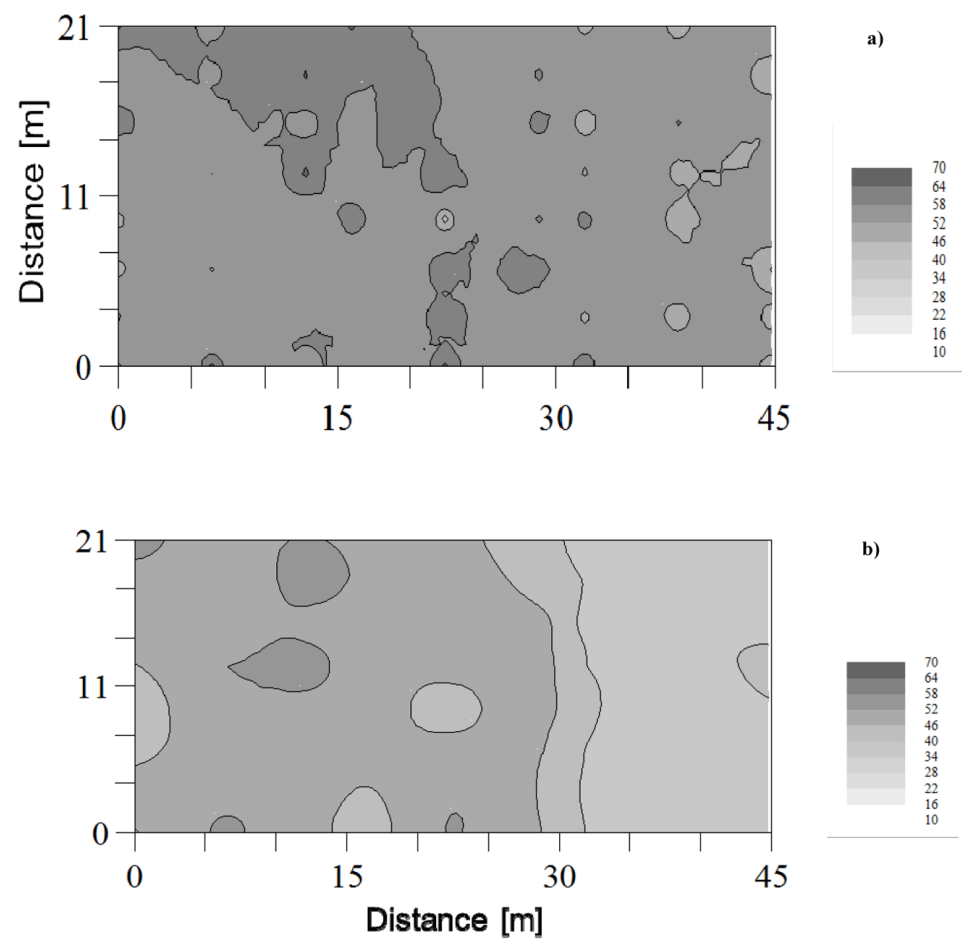

b)

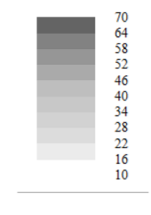

Figure 2. Spatial variability of soil water content [Vol. \%] under saturated conditions (a) and (b) field capacity.

\section{Discussion}

\subsection{Andisol's hydraulic properties}

The importance of determining soil hydraulic properties, their magnitude and influence on the irrigation of a crop is not a new a concern and has been investigated in many soils in the world (Guimaraes et al., 2010; Timm et al., 2010; Zeng et al., 2013). Due to climate change, as well as increasing human population strain on global food production, which principally depends on the water availability, every day sustainable irrigation becomes more vital, especially considering the constant decrease of fresh water resources in the world (Molden et al., 2010). Investigations considering these problems are not rare, however, they are concentrated on soil types derived from other materials than volcanic ashes (Guimaraes however, they are concentrated on soil types derived from other materials than volcanic ashes (Guimaraes et al., 2010). This creates a strong need for information about the hydraulic behaviour of these soil types. The latter becomes even more relevant, taking into account that Andisols constitute over $60 \%$ of arable land in Chile (Besoain and Sepúlveda, 1985) and present very peculiar physical properties (Dörner et al., 2010).

Andisols normally present a low bulk density $(<$ $0.9 \mathrm{~g} \mathrm{~cm}^{-3}$ ), high pore volume, as well as high plant available water, hydraulic and air conductivity (Dörner et al., 2010; Dec et al., 2012). 


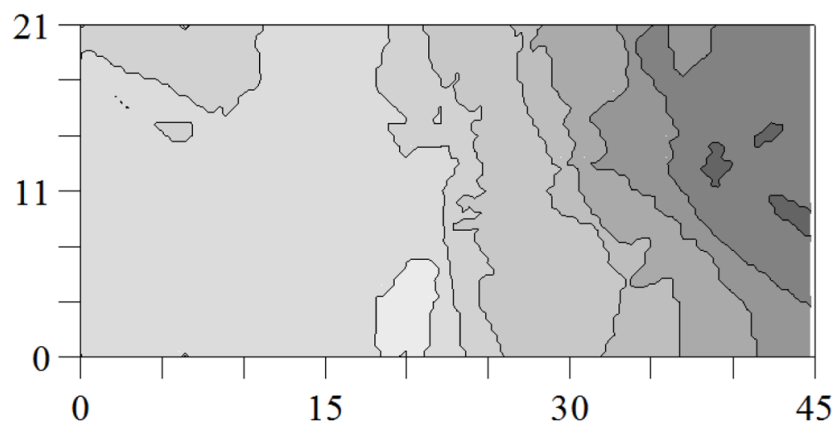

a)

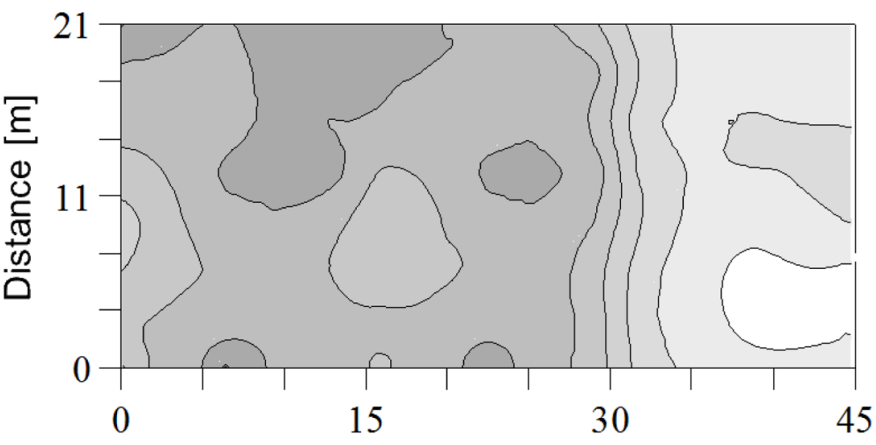

b)
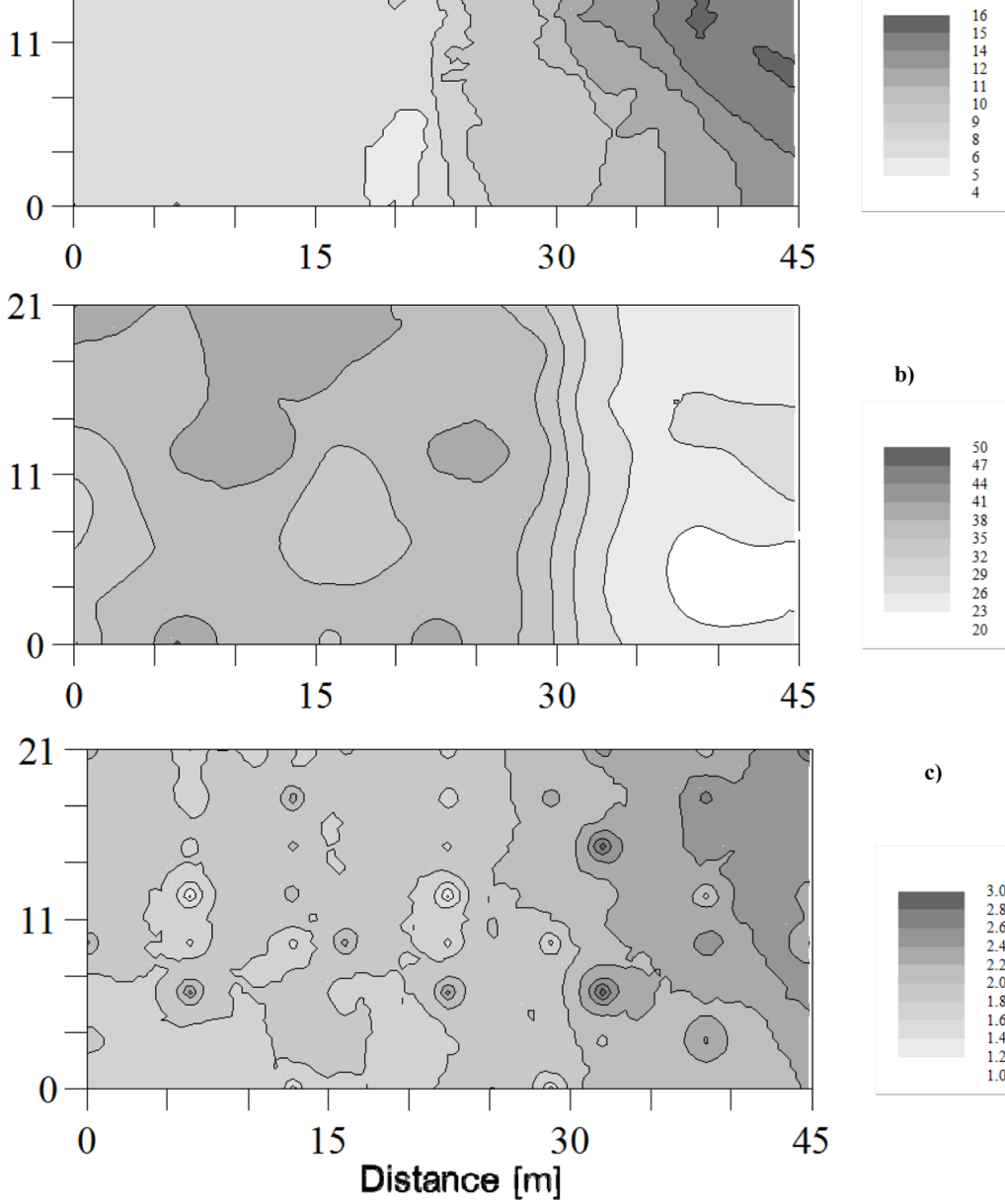

c)

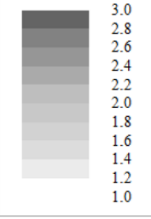

Figure 3. Spatial variability of: (a) water filled macropores [Vol. \%], (b) plant available water [Vol. \%] and (c) saturated hydraulic conductivity [log $\left.\mathrm{cm} \mathrm{d}^{-1}\right]$.

This hydraulic behaviour suggests that they present very good conditions for plant growth. This is demonstrated in the present study: a mean of $33 \%$ of plant available water is in the optimal range for crop production as proposed by Reynolds et al. (2009). On the other hand, from the data obtained from the water retention curves at 5,20 and $50 \mathrm{~cm}$ depths (data not shown), the water storage capacity (available for plants) of this soil at $40 \mathrm{~cm}$ was calculated. This depth was chosen based on the investigations made by Bryla and Strik (2007) who investigating different types of blueberry, assessing that most roots of all cultivars were located at depth less than $40 \mathrm{~cm}$. 


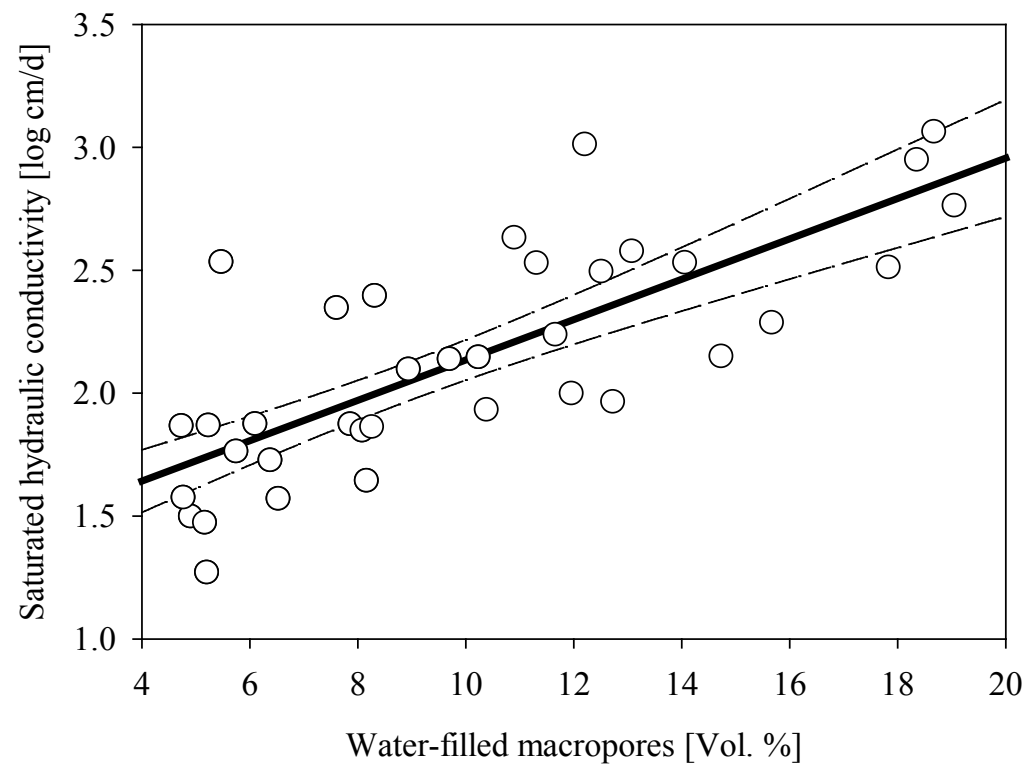

Figure 4. Saturated hydraulic conductivity as a function of water filled macropores.

Also Retamales and Hancock (2012) mentioned this depth as the most used for tensiometers installation to indicate the time of irrigation scheduling. The water storage capacity reached $11.8 \mathrm{~cm}$ at a $40 \mathrm{~cm}$ depth, reflecting the high capacity of these soils to store water. On the other hand, under these conditions a lower irrigation frequency can be used, making the irrigation organization easier, especially if the available water is not sufficient to irrigate the whole area at once. This information, however, is not sufficient in the moment of designing the efficiency of irrigation system, as it needs information about the capacity of the soil to conduct water and air, since this property represents the efficiency of the porous system and further, conditions for the root development.

The results show that this soil provides very good hydraulic, physical and aeration conditions for plant growth. However, investigations carried out by Ellies et al. (1997) show that the capacity of these soils to store and conduct the water under both saturated and unsaturated conditions is so high that it leads to the temporal water contents in ranges not available to plants. This conclusion is also supported by field measurements conducted in volcanic soils by Dörner et al. (2012). In their investigations they registered the temporal variability of the soil water content at three depths $(5,20$ and $50 \mathrm{~cm})$ showing the dynamic behaviour of the soil moisture as a response of the rain events. The soil, at $5 \mathrm{~cm}$ depth, reached almost completely saturation after rain of $80 \mathrm{~mm}$, however, after these precipitations a rapid decrease of the soil water content was observed. After the first dehydration event, soil water content reached $40 \%$, equivalent to a $\mathrm{pF}$ value of 2.8. This situation can be critical, especially for plants, which are susceptible on every water content variation, as in the case of blueberries. In these terms, Holzapfel et al. (2004) mentioned that variable soil water content during the season contributes to a poor growth and yield, especially of Highbush Blueberries. 
In southern Chile, the determination of irrigation parameters frequently follows the traditional method, which in general is based on a permanent irrigation calendar, based on the farmer experience, where the water content is determined by touch or visual observation (information from farmers). These methods do not consider effective soil physical parameters for volcanic soils and their dynamics (temporal and spatial variations; Dec et al., 2011, 2012). This finally leads to an inefficient use of the capabilities of the modern irrigation systems (Holzapfel and Arumi, 2010) without providing the adequate and optimal amount of water to plants. These factors become very relevant, especially, given that the irrigation systems are already under pressure to produce more with reduced supplies of water (Molden et al., 2010).

\subsection{The spatial variability of soil hydraulic parameters}

As mentioned above, a defined structure of spatial variability (Table 2) was observed for soil hydraulic properties related to storage (Figures 1, 2, $3 \mathrm{a}$ and $\mathrm{b}$ ) and conduction of water (Figure $3 \mathrm{c}$ ). The importance of these parameters is manifested in every stage of crop development, as they are related to the water - plant hydraulic relations (Molden et al., 2010). Consideration of their spatial character is then very important in irrigation system design, given periods of intensified water requirement such as fruit ripening when plants use almost $55 \%$ of the total seasonal water requirements (Mingeau et al., 2001). Other authors mentioned also the first 2 weeks after petalfall and the 2 weeks before and after harvest as high water demanding periods. Considering the spatial characteristics for the soil hydraulic properties of the studied Andisols (Figure 1, 2, 3), the irrigation scheduling can be crucial for the water availability for roots. Furthermore, the ability of plant roots to penetrate the soil profile is limited by physical and chemical properties, such as the soil Bd (Figure $1 \mathrm{a}$ ) and the presence of Al, respectively (Valle et al., 2009).

The soil physical properties depend on soil texture and structure (Horn and Smucker, 2005). In this terms, it was assessed that $\left(\theta_{\text {(Field })}\right)$ presented a very weak spatial DD (Table 2), which can be explained by the fact that the measured values were near to the permanent wilting point (PWP). The latter is relevant to understand the spatial-structure dependency, since the PWP depends on soil texture, reflecting the homogeneity of the soil as observed in the field. On the other hand, the saturated hydraulic conductivity (Ks) reached average values of $2 \log \mathrm{cm} \mathrm{d}^{-1}$ (Table 1), presenting, variations between 1 and $3 \log \mathrm{cm}$ $\mathrm{d}^{-1}$ (Figure $3 \mathrm{c}$ ). Investigations made by Ellies et al. (1997) and Dörner et al. (2010), in the same region, obtained Ks of several decimeters, relating them to the low bulk densities, great volume of coarse pores and its continuity. This was also assessed in the present study (Figure 4). As the macropore volume and the continuity of these pores depends on soil structure (Horn and Smucker, 2005), it was expected that Ks presented a high variability (see also Hartge and Horn, 2009), especially when considering that the volume of macropores changes during wetting and drying cycles as a consequence of crack formation (Dörner et al., 2011). The latter affects water distribution in the root zone - a significant factor in designing and management of efficient irrigation systems. The correct determination of Ks becomes significant especially in drip irrigation, since it supplies a small amount of water, but with high frequency when compared with traditional furrow irrigation (Zeng et al., 2013). This type of irrigation together with sprinkler irrigation is the principal method used for Blueberry crops (Bryla, 2011).

Other soil properties, which strongly depend on soil structure, are the water-filled macropore volume (ea (60kPa) and the plan available water (PAW). While the first is relevant for the aeration of the soil after irrigation or rainfall and the potential stress due to water excess, the second indicates the soil water holding capacity and potential stress due to lack of water. The amount of macropores filled with water varies between 4 and $16 \%$, whereas the plant available water reaches $16 \%$. In these terms, zones with larger plant available water were related to 
zones with higher water content under saturated and field conditions (Figure 1, 2 and 3).

The presented results confirm that the consideration of the spatial variability of soil hydraulic properties is very important in the moment of designing efficient irrigation systems that exhibit sustainable water use. This is also mentioned by Timm et al. (2010) and Guimaraes et al. (2010), and is relevant since the lack and excess of water have positive or negative impacts on yield. In the case of Blueberries, this effect is more pronounced due to the characteristics of their roots system. As mentioned above, Blueberries are shallow-rooted plants that are rapidly subjected to drought (Spiers, 1986) or over irrigation (Retamales and Hancock, 2012). Finally, in order to improve the water use efficiency in a scenario of a higher pressure on natural resources and climate change, careful consideration should be taken of the particular physical properties of volcanic ash soils, which can be considered in further investigations in order to improve the water use efficiency in irrigated fields dominated by volcanic ash soils in southern Chile.

\section{Conclusions}

Hydraulic properties, which decide air exchange and water availability for plants, are space dependent in a field modified for Blueberry production. The properties that presented the larger dependence degree (DD) were soil structure-dependent (e.g. bulk density and saturated hydraulic conductivity), whereas, the lowest values were observed for those related to soil texture (in this case the field water content which was close to the permanent wilting point).

The spatial variability was related to the high water storage capacity as well as to the ability of the soil to conduct water with different intensities, which in turn is strongly related to the amount of water-filled macropores.
The consideration of the spatial variability of hydraulic properties in design of irrigation system is very relevant especially for Blueberries, since they have superficial root systems which are very sensitive, not only to water stress, but also, to variations in soil water content. The fulfilling of these conditions is crucial furthermore in this soil type, as they dry very fast, reaching seasonal water content levels that are in ranges not available for plants.

\section{Acknowledgements}

This first author thanks the CONICYT Inserción de Capital Humano Avanzado en la Academia 791100029 for the financial support. The study was also sponsored by the Project of DID S-2012-30.

\section{References}

Besoain, E., Sepulveda, G., 1985. Minerales secundarios. In: Tosso (Eds.), Suelos Volcánicos de Chile. INIA, Santiago, Chile, pp. 153-214.

Bryla, D. 2011. Crop Evapotranspiration and Irrigation Scheduling in Blueberry. U.S. Department of Agriculture, Agricultural Research Service USA. pp. 167-186.

Bryla, D., Strik, B. 2007. Effects of cultivar and plant spacing on the seasonal water requirements of highbush Blueberry. J. Amer. Soc. Hort. SCI. 132(2). pp. 270-277.

Cambardella, C.A., Moorman, T.B., Novak, J.M., Parkin, T.B., Karlen, D.L., Turco, R.F., Konopka, A.E. 1994. Field-scale variability of soil properties in Central Iowa soils. Soil Sci. Soc. Am. J. 58, 1501-1511.

CIREN. 2003. Estudio Agrológico X Región. Descripciones de suelos, materiales y símbolos. Publicación 123. Santiago, Chile. 374 p. 
Day, P.R. 1965. Particle fractionation and particle size analysis. In: Black, C.A., et al. (Ed.), Methods of soil analysis, Part I: Agronomy. 9, pp. 545-567.

Dec, D., Dörner, J. Balochi, O. 2011. Temporal and spatial variability of structure dependent properties of a volcanic ash soil under pasture in southern Chile. Chilean Journal of Agricultural Research. 71 (2); 293-303.

Dec, D., Dörner, J., Balochi, O., López, I. 2012. Temporal dynamics of hydraulic and mechanical properties of an Andosol under grazing. Soil \& Tillage Research. 125, 44-51.

Dörner, J., Dec, D., Peng, X., Horn, R. 2010. Effect of land use change on the dynamic behaviour of structural properties of an Andisol in southern Chile under saturated and unsaturated hydraulic conditions. Geoderma. 159, 189-197.

Dörner, J., Dec, D., Zuñiga, F., Sandoval, P., Horn, R. 2011. Effect of land use change on Andosol's pore functions and their functional resilience after mechanical and hydraulic stresses. Soil and Tillage Research. 115-116, 71-79.

Dörner, J., Dec, D., Feest, E., Vásquez, N., Díaz, M. 2012. Dynamics of soil structure and pore functions of a volcanic ash soil under tillage. Soil and Tillage Research. 125, $52-60$.

Ellies, A., Grez, R., Rámirez, C. 1997. La conductividad hidráulica en fase saturada como herramienta para el diagnóstico de la estructura del suelo. Agrosur 25(1) ; 51-56.

González Zagal, C. 2013. Alternativas para el cultivo de arándanos. Oficina de Estudios y Políticas Agrarias. ODEPA.

Guimaraes, R.M.L., Goncalves, A.C.A., Tormena, C.A., Folegatti, M.V., Blainski, E. 2010. Spatial distribution of physical-hydric properties of a
Nitosols under irrigated bean crops. Eng. Agric., Jaboticabal. 30, 657-669.

Hartge, K.H., Horn, R., 2009. Die physikalische Untersuchung von Böden. E. Schweizerbart'sche Verlagsbuchhandlung, Stuttgart.

Holzapfel, E.A., Hepp, R.F., Mariño, M.A. 2004. Effect of irrigation on fruit production in blueberry. Agricultural Water Management. 67, 173-184.

Holzapfel, E.A., Arumni, J.L. 2010. Tecnología de manejo de agua para una agricultura intensiva sustentable. Editorial Universidad de Concepción. I.S.B.N. 978-956-227-329-9. 145 p.

Horn, R., Smucker, A. 2005. Structure formation and its consequences for gas and water transport in unsaturated arable and forest soils. Soil and Tillage Research. 82, 5-14.

Klute, A. 1986. Methods of soil analysis. Part 1: Physical and mineralogical Methods. 2nd ed. SSSA Book Ser. 5. SSSA, Madison, WI.

Mingeau, M., Perrier, C., Améglio, T. 2001. Evidence of drought sensitive periods from flowering to maturity on highbush blueberry. Scientia Hort. 89, 23-40.

Molden, D., Oweis, T., Steduto, P., Bindraban, P., Hanjra, M.A., Kijne, J. 2010. Improving agricultural water productivity: Between optimism and caution. Agricultural Water Management. 97, 528-535.

Retamales, J.B., Hancock, J.F. 2012. Blueberries. Crop production science in horticulture series; $\mathrm{N}^{\circ} 21$. pp323. ISBN 978-1-84593-826-0.

Reynolds, W.D., Drury, C.F., Tan, C.S., Fox, C.A., Yang, X.M. 2009. Use of indicators and pore volume-function characteristics to quantify soil physical quality. Geoderma. 152 (3-4); 252-263. 
Robertson, G.P. 2008. GS+: Geostatistics for the Environmental Sciences. Gamma Design Software, Plainwell, Michigan USA.

Schwen, A., Bodner, G., Scholl, P., Buchan, G.D., Loiskand, W. 2011. Temporal dynamics of soil hydraulic properties and the water-conducting porosity under different tillage. Soil \& Tillage Research. 113, 89-98.

Spiers, J.M. 1986. Root distribution of "Tifblue" rabbiteye blueberry as influenced by irrigation, incorporated peat moss, and mulch. J. Am. Soc. Hort. Sci. 111, 877-880.

Timm, L.C., Reckziegel, N.L., Sanzi Aquino, L., Bassoi, L.H., Carvalho Guimarães, L.E., Quevedo Tavares, V.E., Vaz, C.L.P., Manieri, J.M., Carvalho Ramos, C.M., De Almeida Ribeiro, P.R., Reichardt, K. 2010. Spatial variability of physical and hydraulic atributes of a Sandy soil in the Northeast Brazil. Suelos Ecuatoriales. 40 (2):139-151
Valle, S., Carrasco, J., Pinochet, D., Calderini, D.F. 2009. Grain yield, above-ground and root biomass of Al-tolerant and Al-sensitive wheat cultivars under different soil aluminum concentrations at field conditions. Plant \& Soil. 318, 299-310.

van Genuchten, M. TH. 1980. A closed-form equation for predicting the hydraulic conductivity of unsaturated soils. Soil Sci. Soc. Amer. J. 44, 892898.

Walkley, A., and Black, I.A. 1934. An examination of Degtjareff method for determining soil organic matter and a proposed modification of the chromic acid titration method. Soil Sci. 37, 29-37.

Zeng, Ch., Wang, Q., Zhang, F., Zhang, J. 2013. Temporal changes in soil hydraulic conductivity with different soil types and irrigation methods. Geoderma. 193-194, 290-299. 